\title{
The cultivation of cross-cultural communicative competence in college English teaching
}

\author{
Zhao guizhen, Lei xianhui \\ Hebei Academy of Fine Arts, Shijiazhuang, Hebei
}

\begin{abstract}
The ultimate goal of foreign language teaching is to cultivate the ability of using target language to communicate with people from different cultural backgrounds. Learning a foreign language is not only to master the pronunciation, grammar, vocabulary and idioms, But also to know the culture of the people who use the language, therefore, the students' ability of intercultural communication must be developed in foreign language teaching. In this paper the current situation and causes of cross-cultural communication ability and countermeasures of cultivating students' cross-cultural communicative competence in college English teaching are expounded in detail.
\end{abstract}

Keywords- college English; cross-cultural; communicative competence

\section{DEFINITION OF CROSS-CULTURAL COMMUNICATION}

As an emerging discipline, cross-cultural communication involves in anthropology, sociology, ethnology, and many other disciplines. Intercultural communication refers to "the communicative process of people with different cultural backgrounds which can also simply summarized as" the process of communicating and interacting of people with different cultural backgrounds ". American scholars Larry (1998) and others defined intercultural communication as" communication between people changed by the differences of cultural consciousness and symbol system in communication event". Chinese scholars Guanshijie believe that cross-cultural communication is the communication between "people or group with a kind of cultural background and people or group with another kind of culture background ". Cross-cultural communication not only refers to the communication which "cross", different races, nationalities, countries or political and economic systems, it also refer to the communication which "cross" different genders, ages, occupations, classes, education levels and even regions in the same country, etc. The author think, cross-cultural communicative competence is mainly composed of pragmatic competence with which learners can reach the goal of effective communication and society and cultural norms- related communication competence including verbal and nonverbal ability, culture ability, interaction ability.

\section{IMPORTANCE OF CULTIVATING CROSS-CULTURAL COMMUNICATION}

College English cross-cultural teaching means emphasizing on target knowledge spreading in the process of college English teaching and related activities in order to make students realize the important significance and function of cross-cultural communication to the modern world, understand the restriction and influence on cultural aspects of human life, especially on communicative activities, be familiar with the basic form of intercultural communication as well as the various factors involved, cultivate students' cross-cultural awareness, forming and developing sensitivity and tolerance to cultural differences as well as the flexibility of dealing with cultural differences. College English crosscultural teaching is both an important part of the crosscultural education and the reflection of the combination of language teaching and culture teaching. The overall goal of cross-cultural foreign language teaching should be improving the students' comprehensive language using ability, forming perfect personality and realizing the allround development, striving to improve the students' intercultural communicative awareness and communicative competence. Without sufficient intercultural communication knowledge, cross-cultural communication ability cannot be improved, let alone communicate interculturally.

\section{COLLEGE ENGLISH TEACHING CAN IMPROVE} STUDENTS' CROSS-CULTURAL COMMUNICATION AWARENESS

In college English teaching, students not only should possess language ability and communication knowledge, but also actively apply the mastered communication knowledge and sensitively analyze cultural phenomenon. Cross-cultural awareness is communicators' sensitive degree to the cultural factors in the process of cross-cultural communication and consciousness $\mathrm{g}$ of adjusting language understanding and output when using foreign languages. Intercultural sensitivity and self-consciousness is the core of the cross-cultural awareness, only by enhancing students' cultural sensitivity and promoting spontaneous formation of cultural consciousness can their knowledge of be full played and used, can students' ability of intercultural communication actually improved. I $\mathrm{n}$ a world of complicated situation and economic integration, students must try to gain insight the cultural affinity behind, pay close attention to the possible cultural conflict and misunderstanding in crosscultural context, understand the possible different choices from foreign cultural mentality, thus improve the crosscultural communicative competence. 


\section{UNIVERSITY ENGLISH CROSS-CULTURAL TEACHING \\ CAN STRENGTHEN STUDENTS' CROSS-CULTURAL PRACTICE AND IMPROVE STUDENTS' CROSS-CULTURAL COMMUNICATIVE COMPETENCE}

All available conditions can be applied in college English cross-cultural teaching to create cross-cultural communication atmosphere, increase students' intercultural communicative activities, improve students' cross-cultural communication skills, so that students can properly use knowledge, proceed cross-cultural communication appropriately and successfully. Differences resulted from speakers' education, English usage as well as their mastery of pragmatic culture rules tend to lead to communication barriers. For example: the Chinese when communicating with foreigners, often fail to understand the so-called American humor and British humor touch mind, thus cannot get the so-called punch line .Positive intercultural communication knowledge accumulation can arouse sensitive cross-cultural communication consciousness which promote the improvement of comprehensive cross-cultural communication ability. Knowledge, consciousness and ability all need to get through cross-cultural foreign language teaching. Therefore, the improvement of intercultural communication ability can and can only be realized in the cross-cultural foreign language teaching.

\section{PROBLEMS EXISTING IN THE COLLEGE ENGLISH CROSS-CULTURAL COMMUNICATION COMPETENCE}

The status quo of college English teaching is not optimistic in our country which attaches great importance to the test, looks down on practical application, makes test results be the important way of teaching evaluation, and fails to explore the social connotation of language. The connotation and practical application of language received great limits. Most of the students think that the text is only Chinese plus English translation, and understand the meaning, that they don't need to understand the connotation meaning behind the language and don't know how to use the language to communicate. The main reasons are as follows:

\section{FROM THE PERSPECTIVE OF TEACHERS'}

\section{A. The teaching ideas bias and lack culture teaching}

With the development of cross-cultural communication, the importance of cross-cultural foreign language teaching in China get more and more attention, and cross-cultural teaching related theoretical research and practical exploration are becoming increasingly rich. But because of the different foundation and environment of cross-cultural education development around the world, cross-cultural foreign language teaching research and practice in our country has just started compared with the European and American countries, and is obviously inadequate in terms of research depth and breadth and systemic. The main reason is that we haven't attach importance to the policy guidance of crosscultural foreign language teaching in China, and the content of the cross-cultural education is insufficient in teaching outline, teaching material, teaching methods, test etc. Teachers introduce cultural background knowledge to students only relying on their own understanding to some extent. Thus culture teaching completely lack guidance and system, and this kind of superficial one-sided culture teaching may to some extent improve the ability of intercultural communication, but in most cases it will lead to the students' narrow, rigid understanding of the culture or even bias. to the alien culture

Among many influence factors which rarely involve culture teaching in college English teaching, teacher factors is the key to deciding whether English culture teaching can be put in place. First, there exist a serious shortage of teacher's own culture training and cultural experience, and cultural consciousness is weak, causing a severe shortage of cultural knowledge with little mastered culture knowledge, no system. Secondly, teachers itself is the product of the traditional English teaching, whose education of ideology is deeply rooted and whose teaching methods and concepts which only attach importance to language forms will naturally reflected in his teaching, and it is the manifestation of teaching concept errors. In class, teachers seldom teach language pragmatic rules and communication techniques and skills, and the introduction of cultural knowledge of English is superficial with no order or system. Some teachers lack adequate understanding of language appropriateness in communication, and fail to give enough attention to the role of social environment factors on communication and cultivation of students' ability, and even some teachers think that cultural teaching is not necessary (WeiZhaoXi 2010:2526).

\section{B. Serious lack of culture teaching}

The foreign language teaching in China for a long time always focus on the teaching of pronunciation, grammar, vocabulary, syntax and discourse structure analysis and so on and a variety of evaluation and test are on this center accordingly. Affected by many linguistic theories such as traditional linguistics, structural linguistics, generative linguistics etc, language itself is considered as research object in the field of college English teaching in China, and we think that training and improving language ability is the ultimate goal of college English teaching, depending on which the mode of language knowledge teaching system is determined. For many years, when it comes to college English teaching, people will naturally think of pronunciation, vocabulary and grammar knowledge teaching, and about what ability should students cultivate in college English teaching, people will say the training and cultivation of five basic language skills: listening, speaking, reading, writing and translation while teaching of cultural knowledge and cultivation of cultural ability are hardly mentioned.. Emphasis is laid on the correctness and fluency of the language form in all kinds of exams, neglecting the social and cultural factors as well as effectiveness and appropriateness of language use which play an important role in communication. Cultural connotation within language forms not mined, communication rules not applied, simple language knowledge learning and language skills training is 
like fish without water, thus cannot revitalize, also won't be able to help students improve their communicative competence and difficult to achieve the goal of English teaching.

In China's foreign language education system, students' foreign language level is measured by exam, and score is the only indication of foreign language level. There is nothing wrong to evaluate the level of students with a test, but the problem lies on the examination methods and content. Because high score represents good performance, a higher level in the eyes of parents and teachers, students often put aside the characteristics of language learning and the cultural connotation contained in languages in English learning focusing on exam questions, specializes in grammar, vocabulary, language points etc. Gradually, scores come up, and teachers and students are satisfied, but all cannot speak English, even if the individual students can speak smoothly and fluently, it is not clear whether they can properly and effectively communicate intercultural. This problem has long plagued our country's foreign language teaching, which has educated many students with weak comprehensive language ability after years of foreign language study .They are likely to have mastered a lot of grammar rules and words, but still cannot communicate appropriately and effectively with foreigners.

\section{Teaching method lag behind, strategy use is not reasonable}

All kinds of cross-cultural teaching methods in foreign language teaching can't be used flexibly and effectively. The current widespread use of Chinese traditional grammar translation method and communicative teaching method is too simple for culture teaching, and to a certain extent hamper the development of culture teaching. The problem of single model exists in teaching methods. In teaching, students' main body effect and the degree of students' autonomous learning is not enough and students' ability of cooperative learning is not strong, which largely concentrate on teachers' teaching and playing, students' listening and watching. Extra-curricular communication activities extended from class teaching is inadequate. In recent years, with the in-depth development of English teaching theory research, the research level increasingly enhances and the new teaching methods emerge and accepted by foreign language teaching. Many college English teachers realize and understand the value of some new teaching methods, such as cognitive approach and communicative approach etc. and gradually try to use them, but the application of new teaching methods are very limited, the traditional teaching method is still dominant.

\section{Lack of understanding and comprehension for differences between Chinese and English}

Before entering the university in our country, college students have been accepted the education of Chinese traditional culture and their way of thinking, code of conduct, ethics has been formed. After university life begins, faced with open social, cultural and life environment of life as well as the introduction of western culture, the existing cultural stereotypes of college students are stricken by western culture, thoughts and values. Cultural conflicts caused by lack of the understanding of cultural differences can make college students encounter all sorts of contradictions and problems in cross-cultural communication which lead to failure in cross-cultural communication. So, the lack of knowledge and ability of social and cultural aspects directly affect the improvement of intercultural communication ability. Lack of language skills will have an effect on crosscultural communication, while the lack of social cultural ability will cause obstacles or even conflicts in cross-cultural communication. Though values of college students has become a pattern, yet incomplete, and cultural differences and conflicts will have a great impact on student's values and world view. Therefore, cultural differences should be treated fairly from the perspective of cross-cultural objective in foreign language teaching. Strengthen students' cultivation of language ability and at the same time, strengthen the cultivation of students' social culture ability, helping students have right attitude towards cultural differences and conflicts, and form a good world outlook and values.

\section{THE MAIN REASON OF CROSS-CULTURAL COMMUNICATION BARRIERS}

\section{A. Thinking mode differences}

Language differences form because of region, races, cultural and people's thinking mode differences, because of. which Chinese and western choose different words in expressing the same idea or meaning. such as: (a piece of cake). Also because of this interference of mother tongue thinking mode, there will be a lot of ambiguous words when students of our country make sentences in learning English, which is very funny, such as: (good good study), (day day up), etc. There are essential differences between Chinese thinking mode and English thinking mode. Traditional thinking mode in our country pay attention to the overall consideration, which requires language expression be simple and clear, but lack reasoning. Western thinking mode is different, which mainly emphasis on science, analysis, and empirical. re was a man in the car" part first, then the whole.

\section{B. Differences in values}

China's past orientation and western future orientation can be presented in the language. The western future orientation shows how to cherish time, for example: Time is money. Differences of Chinese and western in computing age can also reflect time order difference.

\section{WAY OF CULTIVATING STUDENTS' ABILITY IN CROSS- CULTURAL COMMUNICATION}

\section{A. Establish correct teaching idea}

At present, cross-cultural education related ideas is still more frontier idea in China's foreign language world. As education related policy making institution, the understanding and interpretation of the cross-cultural education of state administrative departments will directly 
affect the result of carrying out the cross-cultural education in our country. As a result, experts and leaders of education administrative department should draw lessons from and compare cross-cultural experience of European and American countries, examine the era significance of crosscultural education from a strategic perspective, explicit the goal and content, determine cross-cultural education objectives, principles and methods conforming to the situation of our country, provide basis for foreign language teaching, and clear direction

\section{B. Adopt task-based" method in teaching}

Task-based teaching is acquired through a large number of empirical studies of two languages in which there are some learning tasks, and students proactively search for knowledge, and form interaction by participating. By completing tasks, students can use language knowledge and significance to solve practical problems. Knowledge is inculcated in traditional teaching and was unable to inspire students' initiative regardless of students 'interest,. Taskbased teaching is well combined with cultural teaching, thus can arouse student's interest and initiative, and by completing the task, students can understand the culture connotation behind, better understand the use of language, and actively complete the cultural knowledge learning.

\section{Correct understanding of the relationship between language teaching and culture teaching}

For a long time, this kind of teaching mode causes students focus on grammar, vocabulary and do relevant type test of practice, yet be weak in chapter understanding in the context and communication ability like listening and speaking, therefore, it is especially important to correctly understand and handle the relationship between language teaching and culture teaching.

First, the process of language teaching and culture teaching is simultaneous. Language teaching as well as culture teaching must be conducted by teachers corresponding, which shows that linguistics and acquisition mechanism and culturology and acquisition mechanism is coordinated, synchronized. As ShengYan points out, "ego boundaries" tend to be formed in the process of second language learning. Purpose of learning a second culture is to go beyond the "boundary", or make this "ego boundaries" be extended, to eliminate obstacles from contact of the two cultures, enable learners to think, deal with, solve problems in the position of native target language speakers and eventually achieve the real ideal empathy, get a new "identity".

Second, language teaching and culture teaching are interdependent, conditional, and complementary with each other. To understand a culture must first understand the language, and vice versa. Culture teaching without language teaching, therefore, will become bricks without straw. While the content of language teaching without cultural teaching is boring and unable to stimulate students' interest in learning. From the aspects of ability training, by teaching language knowledge without corresponding cultural knowledge teaching, students can only master the most basic language ability rather than appropriately use language effectively and successfully in cross-cultural communication, thus fail to reach the goal of improving the ability of cross-cultural communication. From cultivating mechanism point, language teaching is the basis and premise condition of culture teaching, at the same time plays the role of opposition and inspection in language teaching, and can promote language teaching, solid language foundation, and improve communication skills. Culture teaching can extend the depth and breadth of language teaching, and effectively improve the quality of language teaching.

Third, Language teaching and culture teaching are compatible, inseparable with each other. The fact that language and culture fuse make us believe that no matter what language teaching method we use, it will naturally lead to cultural teaching. Modern education idea think that only by combining language teaching and culture teaching in foreign language teaching can be the real teaching in the modern sense. Domestic scholars Li Runxin(1994) vividly expressed the relationship of compatibility and fusion between language teaching and culture teaching with chemical formula image as language + culture + teachers (catalyst) $=$ language communicative competence (organic compound). Only by combining organically of language teaching and culture teaching, can the highest purpose of foreign language teaching be achieved and students' real cross-cultural communication ability be attained in education process.

\section{AUTHOR INTRODUCTION}

Zhao guizhen: (1979-), English teacher from Hebei Academy of Fine Arts, Research focus: English teaching.

Lei xianhui: (1979-), English teacher from Hebei Academy of Fine Arts, Research focus: English teaching.

\section{REFERENCES}

[1] Richards, J. C. The Role of Vocabulary Teaching[J]. TESOL Quarterly, 1976, (10):77-89.

[2] Robinson, G. L. N. Cross-Cultural Understanding[M]. Englewood Cliffs, NJ Prentice-Hall, 1988.

[3] Robinson-Stuart, G. \& Nocon, H. Second Culture Acquisition: Ethnography in the Foreign Language Classroom[J]. The Modern Language Journal, 1996, (80):431-449.

[4] Ruben, B. D. The Study of Cross-cultural Competence: Traditions and Contemporary Issues[J]. International Journal of Intercultural Relations, 1989, (13): 229-240.

[5] Samovar,L. A. R. E. Porter. \& L. A. Stefani. Communication between Cultures[M].Beijing: Foreign Language Teaching and Research Press, 2000 . 